\title{
THE EFFECT OF PRODUCTION SYSTEMS ON BEEF FATTY ACID COMPOSITION
}

\author{
Mojca VOLJČ ${ }^{1,2}$, Alenka LEVART ${ }^{1}$, Marko ČEPON ${ }^{1}$, Silvester ŽGUR ${ }^{1}$
}

Received April 05, 2017; accepted November 25, 2018. Delo je prispelo 05. aprila 2017, sprejeto 25. novembra 2018.

\begin{abstract}
The effect of production systems on beef fatty acid composition
The aim of the present study was to evaluate the effect of different production systems on fatty acids (FA) composition of three beef muscles (longissimus thoracis, semitendinosus and diaphragmae). The first group (MGSC) included 8 bulls of Slovenian Brown breed that were fattened with maize, grass silage and concentrates. The second group (MCS) included 8 bulls of Slovenian Simental breed that were fattened with maize silage, ensiled corn grain and concentrates. The third group (GS) included 6 Limousine $\times$ Simmental crossbreed bulls that have been fattened on pasture in cow-calf production system until slaughter. In fourth group (G) 8 bulls of Slovenian Simmental breed were fattened on pasture from spring to autumn when they were slaughtered. Bulls from MSC and MGSC had similar carcass weight ( $316 \mathrm{~kg}, 308 \mathrm{~kg}$, respectively), whereas bulls from GS had the lightest $(215 \mathrm{~kg})$ and bulls from $\mathrm{G}$ the heaviest carcass weight $(371 \mathrm{~kg})$. Carcass fatness was similar for bulls in MSC, MGSC and G groups and slightly lower in GS group. The percentage of saturated FA differed among groups only in semitendinosus muscle. Bulls from G and GS had lower percentage of monounsaturated FA (MUFA) and higher percentage of polyunsaturated FA (PUFA) in all three muscles. Bulls from grazing production systems had higher $n-3$ PUFA values in all muscles and higher n-6 PUFA values in semitendinosus and diaphragmae. Bulls fattened on pasture had lower $n-6 / n-3$ ratio in all three muscles. Bulls from GS had a higher percentage of conjugated linolenic acid in comparison to MGSC and MCS groups in all muscles except in semitendinosus where percentage of CLA was higher only from MGSC group.
\end{abstract} acid
Key words: production system; beef muscle; grazing; fatty
Vpliv načina reje na maščobnokislinsko sestavo mišic bikov Namen raziskave je bilo oceniti vpliv različnih načinov reje bikov na maščobnokislinsko sestavo (MK) treh mišic (longissimus thoracis, semitendinosus in diaphragmae). Prvo skupino (MGSC) je sestavljalo 8 bikov rjave pasme, ki so bili krmljeni s koruzno in travno silažo ter močno krmo. V drugi skupini (MCS) je bilo 8 bikov lisaste pasme, ki so bili krmljeni s koruzno silažo, s siliranim mletim koruznim zrnjem ter močno krmo. Tretja skupina (GS) je vključevala 6 bikov križancev med limuzin in lisasto pasmo, ki so bili ves čas do zakola na paši ob svojih materah dojiljah. V četrti skupini $(G)$ je bilo 8 bikov lisaste pasme, ki so bili na paši zadnjo fazo pitanja to je od spomladi in pa do zakola, ki je potekal jeseni. Biki iz skupine MGSC in MCS so imeli podobno maso klavnih trupov, to je 316 in $308 \mathrm{~kg}$. Biki iz skupine GS so imeli najmanjšo maso zaklanih trupov $(215 \mathrm{~kg})$, medtem ko so bili biki iz G skupine najtežji $(371 \mathrm{~kg})$. Zamaščenost klavnih polovic je bila podobna pri MSC, MGSC in G bikih in malo manjša pri GS bikih. Vsebnost nasičenih MK se je med skupinami razlikovala samo $\mathrm{v}$ semitendinosus. Biki s paše so imeli v vseh treh mišicah večjo vsebnost enkrat (ENMK) in večkrat nenasičenih MK (VNMK). Biki spitani na paši so imeli tudi večjo vsebnost n-3 VNMK v vseh treh mišicah, medtem ko je bila značilna večja vsebnost n-6 VNMK samo v mišici semitendinosus in diaphragmae. Biki $s$ paše so imeli tudi ožje razmerje n-3/n-6 VNMK v vseh treh mišicah. v Biki iz GS skupine so imeli tudi večjo vsebnost konjugirane linolne kisline $\mathrm{v}$ primerjavi $\mathrm{z}$ biki iz MGSC in MCS skupine v vseh mišicah razen v semitendinosus, kjer je bila vsebnost višja le v primerjavi z MGSC skupino. ne kisline

Ključne besede: govedo; biki; načini reje; mišice; maščob-

1 University of Ljubljana, Biotechnical Faculty, Department of Animal Science, Domžale, Slovenia

2 Corresponding author, e-mail: mojca.voljc@bf.uni-lj.si 


\section{INTRODUCTION}

Different production systems have been shown to significantly alter the fatty acid (FA) composition of beef. Manipulating FA composition of ruminant fat by changing their diet is far more difficult than in monogastric animals, due to the process of biohydrogenation in the rumen (Muller and Delahoy, 2004). Nevertheless, the results of many studies confirmed that FA composition of ruminant fat can be affected by different feeding managements (De la Fuente et al., 2009; Humanda et al., 2012; Cividini et al., 2014). The preferential fat composition of beef raised on pasture is well documented, rather than using conserved forage (Alfaia et al., 2009; De la Fuente et al., 2009; Humanda et al., 2012). Human nutrition guidelines recommend reduction in the intake of total fat, saturated (SFA) and trans FA $(t \mathrm{FA})$, on the other hand they advocate the increased intake of $n-3$ polyunsaturated FA (PUFA), especially long chain PUFA (Shinfield et al., 2008). The beneficial fat composition of beef raised on the pasture is well documented and proven superior to conserved forage (Alfaia et al., 2009; De la Fuente et al., 2009; Humanda et al., 2012).

There are two main types of beef production systems in Slovenia. One production system is based on bulls fed maize silage and concentrates and other is based on grazing. Grass-based beef production systems are low-input systems and therefore economically advantageous due to lower production costs. In Slovenia 60 of agricultural area is under permanent grassland and pastures and therefore there is a big opportunity to produce quality beef meat.

The objective of this study was to investigate the impact of production system on FA profile of three beef muscles, by comparing two pasture-based systems and two conventional production systems with maize silage and concentrates in the diets.

\section{MATERIAL AND METHODS}

\subsection{ANIMALS}

The study included thirty bulls which were fattened in four different production systems. In two groups the bulls were fattened indoors and the feeding regime was based on silage and concentrate. Another two groups of bulls were raised in pasture-based feeding regime. The first group MGSC included 8 bulls from the progeny testing (Slovenian Brown cattle breed). They were fattened with the diet which consisted of maize silage $(40 \%$ in dry matter $(\mathrm{DM})$ ), grass silage ( $35 \%$ in $\mathrm{DM})$ and concentrates $(25 \%$ in DM). Concentrates were composed of maize (71\%), barley ( $24 \%)$ and mineral-vitamin pre- $\operatorname{mix}(5 \%)$. This feeding regime was carried out from live weight of $400 \mathrm{~kg}$ live weight to the slaughter at around $550 \mathrm{~kg}$ of live weight. The second group MSC included 8 bulls from the progeny testing (Slovenian Simmental breed) and their diet consisted of maize silage ( $85 \%$ in $\mathrm{DM})$, maize grain silage ( $8 \%$ in DM), soya meal (3\% in $\mathrm{DM})$, sunflower meal (3 \% in DM) and mineral-vitamin premix ( $1 \%$ in DM). These bulls were slaughtered at slightly higher live weight as those of MGSC group. The third group GS included 6 Limousine $\times$ Simmental crossbreed bulls that were fattened on pasture in cow-calf production system. After winter calving, the cows together with their calves were transposed from the stall to the grassland and stayed there until the end of the pasture season in late autumn when the young bulls were slaughtered. The pasture was composed from various grass and clover sorts. The fourth group G included 8 bulls of Slovenian Simmental breed fattened on pasture from spring to autumn and slaughtered at age less than two years. The animals in the GS and G group were on the pasture without any additional components in the diet, except salt and minerals.

\subsection{POST-SLAUGHTER SAMPLING AND MEAS- UREMENT}

After the slaughter, warm carcasses were weighted and carcass conformation and fatness were evaluated according to the EUROP classification system (Table 1). Samples of longissimus thoracis were taken between the $6^{\text {th }}$ and $7^{\text {th }}$ vertebra, semitendinosus and diaphragmae muscles were collected from the right carcass side. Muscle samples were vacuum-packed, rapidly frozen and stored at $-70{ }^{\circ} \mathrm{C}$ until analysis of FA composition.

The FA composition of muscle samples was analysed using a gas chromatographic method following transesterification of lipids. Fatty acid methyl esters (FAME) were prepared according to Park and Goins (1994) using gas chromatograph (6890 series, Agilent, Santa Clara, CA, USA). Separation of FAMEs was performed on capillary column Omegawax ${ }^{\mathrm{TM}} 320(30 \mathrm{~m} \times 0.32 \mathrm{~mm} \times 0.25 \mu \mathrm{m}$ film thickness). Agilent GC ChemStation was used for data acquisition and processing. Individual FAMEs were identified by comparison of retention times with those of standard mixtures and quantified using response factors derived from quantitative standards (NuCheck) and nonadecanoic acid (C19:0) as internal standard. Total fat was calculated as sum of all identified fatty acids $(\mathrm{g} / 100 \mathrm{~g}$ of sample), divided by factor 0.916 (lean beef), to include the glycerol of the triglycerides, phosphate from phospholipids and unsaponifiable components (McClance, 1998). The fatty acid composition of muscle samples was 
Table 1: Carcass weight, conformation and fatness grading for bulls from different production systems

\begin{tabular}{llll}
\hline Group & Carcass weight $(\mathrm{kg})$ & Conformation $^{\star}$ & Fatness $^{* *}$ \\
\hline MGSC & $307.8 \pm 19.9$ & $3.1 \pm 0.4$ & $2.8 \pm 0.5$ \\
MSC & $316.0 \pm 15.1$ & $4.0 \pm 0.5$ & $3.0 \pm 0.0$ \\
GS & $214.7 \pm 33.3$ & $3.5 \pm 0.6$ & $2.5 \pm 0.6$ \\
G & $370.8 \pm 40.1$ & $3.5 \pm 0.5$ & $2.8 \pm 0.5$ \\
\hline
\end{tabular}

* EUROP conformation, where $\mathrm{E}=5, \mathrm{U}=4, \mathrm{R}=3, \mathrm{O}=2, \mathrm{P}=1$

${ }^{* *}$ EUROP fatness, grades 1 to 5

expressed as a weight percentage (wt\%) of the total identified fatty acids.

Data were analysed using the statistical package SAS/STAT (SAS, 2001) using a General Linear Model (GLM) procedure. The model included production system as fixed effect for each muscle separately. Post hoc comparison among the least square means was performed using a Tukey multiple test correction. Levels of significance of differences between groups are given at $p \leq 0.05$.

\section{RESULTS AND DISCUSSION}

Manipulating FA composition in ruminants has been extensively studied with a purpose to reduce SFA and elevate PUFA concentrations. Though dietary manipulation proved to have the most significant effect on fatty acid composition (Scollan et al., 2014, Shingfield et al., 2013), the effect of genetics can not be neglected, as several authors reported differences between breeds (as reviewed by Wood and Enser, 2017). In our study the effect of production system include also the effect of breed

Table 2: Fatty acid composition (wt\%) of muscle longisimus thoracis from bulls fattened in different production systems

\begin{tabular}{|c|c|c|c|c|}
\hline & $\begin{array}{l}\text { MGSC } \\
\mathrm{LSM} \pm \mathrm{SEM}\end{array}$ & $\begin{array}{l}\text { MSC } \\
\mathrm{LSM} \pm \text { SEM }\end{array}$ & $\begin{array}{l}\text { GS } \\
\mathrm{LSM} \pm \mathrm{SEM}\end{array}$ & $\begin{array}{l}\mathrm{G} \\
\mathrm{LSM} \pm \mathrm{SEM}\end{array}$ \\
\hline Total fat $\mathrm{g} / 100 \mathrm{~g}$ muscle & $2.88 \pm 0.29^{a}$ & $1.83 \pm 0.29^{\mathrm{ab}}$ & $2.05 \pm 0.34^{\mathrm{ab}}$ & $1.36 \pm 0.29^{b}$ \\
\hline \multicolumn{5}{|l|}{ Fatty acid, (wt\%) } \\
\hline Lauric (C12:0) & $0.07 \pm 0.01^{\mathrm{a}}$ & $0.02 \pm 0.01^{\mathrm{b}}$ & $0.13 \pm 0.03^{c}$ & $0.01 \pm 0.02^{\mathrm{b}}$ \\
\hline Myristic (C14:0) & $2.73 \pm 0.18^{\mathrm{ad}}$ & $2.16 \pm 0.18^{\mathrm{ab}}$ & $3.39 \pm 0.21^{\mathrm{cd}}$ & $1.74 \pm 0.18^{\mathrm{b}}$ \\
\hline Palmitic (C16:0) & $25.64 \pm 0.70^{\mathrm{a}}$ & $23.10 \pm 0.70^{\mathrm{ab}}$ & $23.51 \pm 0.81^{\mathrm{a}}$ & $20.50 \pm 0.70^{\mathrm{b}}$ \\
\hline Stearic (C18:0) & $14.21 \pm 0.67^{\mathrm{a}}$ & $17.39 \pm 0.67^{\mathrm{bc}}$ & $14.60 \pm 0.77^{\mathrm{ac}}$ & $17.93 \pm 0.67^{\mathrm{b}}$ \\
\hline Oleic $(\mathrm{C} 18: 1)^{\star}$ & $37.80 \pm 0.95^{\mathrm{a}}$ & $35.62 \pm 0.95^{\mathrm{a}}$ & $29.84 \pm 1.09^{\mathrm{b}}$ & $31.41 \pm 0.95^{\mathrm{b}}$ \\
\hline Linoleic (C18:2n-6) & $7.54 \pm 1.04^{\mathrm{a}}$ & $9.43 \pm 1.04^{\mathrm{ab}}$ & $11.09 \pm 1.20^{\mathrm{ab}}$ & $11.81 \pm 1.04^{\mathrm{b}}$ \\
\hline a-linolenic (C18:3n-3) & $0.87 \pm 0.15^{\mathrm{a}}$ & $0.60 \pm 0.15^{\mathrm{a}}$ & $2.01 \pm 0.17^{\mathrm{b}}$ & $3.07 \pm 0.15^{c}$ \\
\hline CLA(c9, t11 C18:2) & $0.29 \pm 0.06^{\mathrm{a}}$ & $0.32 \pm 0.06^{\mathrm{a}}$ & $0.63 \pm 0.06^{\mathrm{b}}$ & $0.50 \pm 0.06^{\mathrm{ab}}$ \\
\hline Arachidic (C20:0) & $0.10 \pm 0.01^{\mathrm{ab}}$ & $0.14 \pm 0.01^{\mathrm{a}}$ & $0.07 \pm 0.01^{\mathrm{b}}$ & $0.14 \pm 0.01^{\mathrm{a}}$ \\
\hline ETA (C20:3n-6) & $0.35 \pm 0.09$ & $0.69 \pm 0.09$ & $0.71 \pm 0.10$ & $0.66 \pm 0.09$ \\
\hline Arachidonic (C20:4n-6) & $2.10 \pm 0.35$ & $2.99 \pm 0.35$ & $3.02 \pm 0.40$ & $2.72 \pm 0.35$ \\
\hline EPA (C20:5n-3) & $0.18 \pm 0.12^{\mathrm{a}}$ & $0.15 \pm 0.12^{\mathrm{a}}$ & $0.96 \pm 0.14^{\mathrm{b}}$ & $0.85 \pm 0.12^{\mathrm{b}}$ \\
\hline DHA (C22:6n-3) & $0.05 \pm 0.03^{\mathrm{a}}$ & $0.01 \pm 0.03^{\mathrm{a}}$ & $0.21 \pm 0.03^{\mathrm{b}}$ & $0.10 \pm 0.03^{\mathrm{ab}}$ \\
\hline SFA & $45.22 \pm 1.14$ & $45.39 \pm 1.14$ & $45.32 \pm 1.31$ & $43.34 \pm 1.14$ \\
\hline MUFA & $42.76 \pm 1.08^{\mathrm{a}}$ & $39.46 \pm 1.08^{\mathrm{a}}$ & $34.04 \pm 1.25^{\mathrm{b}}$ & $34.96 \pm 1.08^{b}$ \\
\hline PUFA & $12.14 \pm 1.65^{\mathrm{a}}$ & $15.20 \pm 1.65^{\mathrm{ac}}$ & $20.69 \pm 1.91^{\mathrm{bc}}$ & $21.74 \pm 1.65^{\mathrm{b}}$ \\
\hline n-3 PUFA & $1.56 \pm 0.39^{\mathrm{a}}$ & $1.23 \pm 0.39^{\mathrm{a}}$ & $4.71 \pm 0.45^{\mathrm{b}}$ & $5.50 \pm 0.39^{\mathrm{b}}$ \\
\hline n-6 PUFA & $10.22 \pm 1.45$ & $13.65 \pm 1.45$ & $15.14 \pm 1.68$ & $15.45 \pm 1.45$ \\
\hline PUFA/SFA & $0.27 \pm 0.04^{a}$ & $0.34 \pm 0.04^{\mathrm{ab}}$ & $0.47 \pm 0.05^{\mathrm{b}}$ & $0.50 \pm 0.04^{b}$ \\
\hline$n-6 / n-3$ & $6.55 \pm 0.38^{\mathrm{a}}$ & $11.10 \pm 0.38^{\mathrm{b}}$ & $3.56 \pm 0.44^{c}$ & $2.86 \pm 0.38^{c}$ \\
\hline
\end{tabular}

LSM = least square means; $S E M=$ standard error of LSM.

$\mathrm{a}, \mathrm{b}, \mathrm{c}=$ LSM with different letters in the same row significantly differ (Tukey post hoc test, $p<0.05$ )

CLA = conjugated linoleic acid; ETA = eicosatrienoic acid; EPA = eicosapentaenoic acid; DHA = docosahexaenoic acid; SFA = saturated fatty acids, MUFA $=$ monounsaturated fatty acids, PUFA $=$ polyunsaturated fatty acids

*sum of isomers of octadecenoic acid 
Table 3: Fatty acid composition (wt\%) of muscle semitendinosus from bulls fattened in different production systems

\begin{tabular}{|c|c|c|c|c|}
\hline & $\begin{array}{l}\text { MGSC } \\
\mathrm{LSM} \pm \mathrm{SEM}\end{array}$ & $\begin{array}{l}\text { MSC } \\
\mathrm{LSM} \pm \mathrm{SEM}\end{array}$ & $\begin{array}{l}\text { GS } \\
\mathrm{LSM} \pm \mathrm{SEM}\end{array}$ & $\begin{array}{l}\mathrm{G} \\
\mathrm{LSM} \pm \mathrm{SEM}\end{array}$ \\
\hline Total fat, $g / 100 \mathrm{~g}$ muscle & $1.20 \pm 0.13$ & $1.11 \pm 0.13$ & $0.85 \pm 0.15$ & $0.79 \pm 0.13$ \\
\hline \multicolumn{5}{|l|}{ Fatty acid, (wt\%) } \\
\hline Myristic (C14:0) & $1.56 \pm 0.17$ & $1.42 \pm 0.17$ & $1.71 \pm 0.19$ & $1.06 \pm 0.17$ \\
\hline Palmitic (C16:0) & $21.82 \pm 0.75^{\mathrm{a}}$ & $19.74 \pm 0.75^{\mathrm{ab}}$ & $19.29 \pm 0.86^{\mathrm{ab}}$ & $16.96 \pm 0.75^{\mathrm{b}}$ \\
\hline Stearic (C18:0) & $14.24 \pm 0.49^{\mathrm{ab}}$ & $14.60 \pm 0.49^{\mathrm{a}}$ & $12.52 \pm 0.56^{\mathrm{b}}$ & $14.40 \pm 0.49^{\mathrm{ab}}$ \\
\hline Oleic $(\mathrm{C} 18: 1)^{\star}$ & $35.09 \pm 1.37^{\mathrm{a}}$ & $30.45 \pm 1.37^{\mathrm{a}}$ & $24.63 \pm 1.58^{\mathrm{b}}$ & $24.50 \pm 1.37^{\mathrm{b}}$ \\
\hline Linoleic (C18:2n-6) & $12.30 \pm 1.48^{\mathrm{a}}$ & $16.26 \pm 1.48^{\mathrm{ac}}$ & $18.94 \pm 1.70^{\mathrm{bc}}$ & $20.50 \pm 1.48^{\mathrm{bc}}$ \\
\hline a-linolenic (C18:3n-3) & $1.05 \pm 0.31^{\mathrm{a}}$ & $0.91 \pm 0.31^{\mathrm{a}}$ & $2.80 \pm 0.36^{\mathrm{b}}$ & $4.95 \pm 0.31^{\mathrm{c}}$ \\
\hline CLA(c9, t11 C18:2) & $0.19 \pm 0.04^{\mathrm{a}}$ & $0.27 \pm 0.04^{\mathrm{ab}}$ & $0.41 \pm 0.05^{\mathrm{b}}$ & $0.33 \pm 0.04^{\mathrm{ab}}$ \\
\hline Arachidic (C20:0) & $0.16 \pm 0.02^{\mathrm{a}}$ & $0.11 \pm 0.02^{\mathrm{ab}}$ & $0.06 \pm 0.02^{\mathrm{b}}$ & $0.09 \pm 0.02^{\mathrm{ab}}$ \\
\hline ETA (C20:3n-6) & $0.81 \pm 0.15^{\mathrm{a}}$ & $1.40 \pm 0.15^{\mathrm{b}}$ & $1.50 \pm 0.17^{\mathrm{b}}$ & $1.20 \pm 0.15^{\mathrm{ab}}$ \\
\hline Arachidonic (C20:4n-6) & $4.29 \pm 0.54$ & $6.30 \pm 0.54$ & $6.44 \pm 0.62$ & $5.18 \pm 0.54$ \\
\hline EPA (C20:5n-3) & $0.38 \pm 0.18^{\mathrm{a}}$ & $0.38 \pm 0.18^{\mathrm{a}}$ & $1.97 \pm 0.21^{\mathrm{b}}$ & $1.68 \pm 0.18^{\mathrm{b}}$ \\
\hline DHA (C22:6n-3) & $0.12 \pm 0.03 \mathrm{a}^{\mathrm{b}}$ & $0.04 \pm 0.03^{\mathrm{a}}$ & $0.37 \pm 0.04^{\mathrm{c}}$ & $0.18 \pm 0.03^{\mathrm{b}}$ \\
\hline SFA & $40.07 \pm 1.18^{\mathrm{a}}$ & $38.19 \pm 1.18^{\mathrm{ab}}$ & $36.24 \pm 1.37^{\mathrm{ab}}$ & $34.86 \pm 1.18^{\mathrm{b}}$ \\
\hline MUFA & $39.45 \pm 1.49^{\mathrm{a}}$ & $34.38 \pm 1.49^{\mathrm{a}}$ & $28.10 \pm 1.72^{\mathrm{b}}$ & $28.34 \pm 1.49^{\mathrm{b}}$ \\
\hline PUFA & $20.59 \pm 2.39^{\mathrm{a}}$ & $27.58 \pm 2.39^{\mathrm{ac}}$ & $35.67 \pm 2.76^{\mathrm{bc}}$ & $36.97 \pm 2.39^{\mathrm{b}}$ \\
\hline n-3 PUFA & $2.42 \pm 0.61^{\mathrm{a}}$ & $2.27 \pm 0.61^{\mathrm{a}}$ & $7.90 \pm 0.70^{\mathrm{b}}$ & $9.33 \pm 0.61^{b}$ \\
\hline n-6 PUFA & $17.96 \pm 2.12^{\mathrm{a}}$ & $25.05 \pm 2.12^{\mathrm{ac}}$ & $27.30 \pm 2.54^{\mathrm{bc}}$ & $27.26 \pm 2.12^{\mathrm{bc}}$ \\
\hline PUFA/SFA & $0.53 \pm 0.08^{\mathrm{a}}$ & $0.75 \pm 0.08^{\mathrm{ac}}$ & $0.99 \pm 0.10^{\text {bcd }}$ & $1.08 \pm 0.08^{\mathrm{d}}$ \\
\hline$n-6 / n-3$ & $7.42 \pm 0.36^{\mathrm{a}}$ & $11.02 \pm 0.36^{\mathrm{b}}$ & $3.75 \pm 0.41^{\mathrm{c}}$ & $3.00 \pm 0.36^{c}$ \\
\hline
\end{tabular}

LSM = least square means; SEM = standard error of LSM.

$\mathrm{a}, \mathrm{b}, \mathrm{c}=\mathrm{LSM}$ with different letters in the same row significantly differ (Tukey post hoc test, $p<0.05$ )

CLA = conjugated linoleic acid; ETA = eicosatrienoic acid; EPA = eicosapentaenoic acid; DHA = docosahexaenoic acid; $\mathrm{SFA}=$ saturated fatty acids, MUFA = monounsaturated fatty acids, PUFA = polyunsaturated fatty acids

${ }^{*}$ sum of isomers of octadecenoic acid

and age/weight as especially GS group included younger bulls that were slaughtered at much lower weight. So we have to keep this in mind and caution is required when generalising the presented results. Nevertheless, we believe that this four production systems with used breeds are most common beef production systems in Slovenia and therefore of particular interest.

The total fat content was the lowest in the G group where animals were fattened on pasture, but the difference was significant only between MGSC and G group. This difference is probably due to the fact that animals in this two production systems belong to different breeds and received different diets. As reported by Kamihiro et al. (2015) both nutrition and genetics affect the level of fat in beef. The levels of SFA in beef are of nutritional importance since SFA tends to dominate in ruminant fat. This is due to the biohydrogenation process in the rumen, where dietary PUFA are being hydrogenated by microbial population. Nutritional guidelines recommend a reduction of total fat intake, particularly of SFA $(\mathrm{DACH}$, 2008). The lauric (C12:0), myristic C14:0) and palmitic (C16:0) acids increase LDL cholesterol whereas stearic (C18:0) has no effect (FAO, 2010).

In this study there was no difference in total SFA percentage in longissimus thoracis among groups but the differences were found for individual SFA. G bulls had the lowest percentage of myristic acid (C14:0) and palmitic acid (C16:0) but the difference was not significant from MSC group. The percentage of stearic acid (C18:0) was lower in MGSC and MS group. Bulls from grazing and suckling production system had the lowest amount of arachidic acid (C20:0) in longissimus thoracis (Table 2). Compared to other muscles, the lowest percentage of SFA was determined in the semitendinosus (Table 3). Animals from group $\mathrm{G}$ had the lowest percentage of SFA in this muscle. Grazing and suckling animals also had lower percentage of SFA but the difference from MGSC and MSC group was not significant. Individual SFA in 
Table 4: Fatty acid composition (wt\%) of muscle diaphragmae from bulls fattened in different production systems

\begin{tabular}{|c|c|c|c|c|}
\hline & $\begin{array}{l}\mathrm{MGSC} \\
\mathrm{LSM} \pm \mathrm{SEM}\end{array}$ & $\begin{array}{l}\mathrm{MSC} \\
\mathrm{LSM} \pm \mathrm{SEM}\end{array}$ & $\begin{array}{l}\mathrm{GS} \\
\mathrm{LSM} \pm \mathrm{SEM}\end{array}$ & $\begin{array}{l}\mathrm{G} \\
\mathrm{LSM} \pm \mathrm{SEM}\end{array}$ \\
\hline Total fat, g/100g muscle & $5.72 \pm 0.55^{\mathrm{a}}$ & $4.62 \pm 0.55^{\mathrm{ab}}$ & $4.25 \pm 0.55^{\mathrm{ab}}$ & $3.33 \pm 0.55^{\mathrm{b}}$ \\
\hline \multicolumn{5}{|l|}{ Fatty acid, (wt\%) } \\
\hline Lauric (C12:0) & $0.05 \pm 0.01^{\mathrm{a}}$ & $0.07 \pm 0.01^{\mathrm{a}}$ & $0.19 \pm 0.01^{\mathrm{b}}$ & $0.05 \pm 0.01^{\mathrm{a}}$ \\
\hline Myristic (C14:0) & $2.22 \pm 0.20^{\mathrm{a}}$ & $2.33 \pm 0.20^{\mathrm{a}}$ & $4.04 \pm 0.23^{b}$ & $2.00 \pm 0.20^{\mathrm{a}}$ \\
\hline Palmitic (C16:0) & $22.37 \pm 0.63^{\mathrm{a}}$ & $21.61 \pm 0.63^{\mathrm{ab}}$ & $22.74 \pm 0.73^{\mathrm{a}}$ & $19.16 \pm 0.63^{b}$ \\
\hline Stearic (C18:0) & $20.98 \pm 0.94$ & $21.84 \pm 0.94$ & $19.39 \pm 1.09$ & $22.54 \pm 0.94$ \\
\hline Oleic $(\mathrm{C} 18: 1)^{\star}$ & $36.36 \pm 1.06^{\mathrm{a}}$ & $34.32 \pm 1.06^{\mathrm{a}}$ & $28.62 \pm 1.22^{\mathrm{b}}$ & $29.00 \pm 1.06^{\mathrm{b}}$ \\
\hline Linoleic (C18:2n-6) & $7.58 \pm 1.00^{\mathrm{a}}$ & $8.66 \pm 1.00^{\mathrm{ab}}$ & $9.85 \pm 1.16^{\mathrm{ab}}$ & $11.91 \pm 1.00^{\mathrm{b}}$ \\
\hline a-linolenic (C18:3n-3) & $0.84 \pm 0.18^{a}$ & $0.61 \pm 0.18^{\mathrm{a}}$ & $1.91 \pm 0.21^{\mathrm{b}}$ & $3.10 \pm 0.18^{c}$ \\
\hline $\mathrm{CLA}(\mathrm{c} 9, \mathrm{t} 11 \mathrm{C} 18: 2)$ & $0.31 \pm 0.06^{\mathrm{a}}$ & $0.34 \pm 0.06^{\mathrm{a}}$ & $0.72 \pm 0.07^{b}$ & $0.49 \pm 0.06^{\mathrm{ab}}$ \\
\hline Arachidic (C20:0) & $0.14 \pm 0.01$ & $0.14 \pm 0.01$ & $0.12 \pm 0.01$ & $0.14 \pm 0.01$ \\
\hline ETA (C20:3n-6) & $0.19 \pm 0.05^{\mathrm{a}}$ & $0.38 \pm 0.05^{\mathrm{ab}}$ & $0.45 \pm 0.06^{\mathrm{b}}$ & $0.40 \pm 0.05^{\mathrm{b}}$ \\
\hline Arachidonic (C20:4n-6) & $1.55 \pm 0.27$ & $2.12 \pm 0.27$ & $2.16 \pm 0.31$ & $2.55 \pm 0.27$ \\
\hline EPA ( C20:5n-3) & $0.09 \pm 0.07^{\mathrm{a}}$ & $0.09 \pm 0.07^{\mathrm{a}}$ & $0.41 \pm 0.078^{b}$ & $0.64 \pm 0.07^{\mathrm{b}}$ \\
\hline DHA ( C22:6n-3) & $0.03 \pm 0.01^{\mathrm{a}}$ & $0.03 \pm 0.01^{\mathrm{a}}$ & $0.10 \pm 0.01^{\mathrm{b}}$ & $0.08 \pm 0.01^{\mathrm{b}}$ \\
\hline SFA & $48.63 \pm 1.26$ & $49.13 \pm 1.26$ & $50.84 \pm 1.46$ & $47.24 \pm 1.26$ \\
\hline MUFA & $40.15 \pm 1.89^{a}$ & $37.86 \pm 1.89^{\mathrm{a}}$ & $32.29 \pm 1.37^{\mathrm{b}}$ & $32.00 \pm 1.89^{b}$ \\
\hline PUFA & $11.25 \pm 1.48^{\mathrm{a}}$ & $13.04 \pm 1.48^{\mathrm{a}}$ & $16.92 \pm 1.71^{\mathrm{ab}}$ & $20.85 \pm 1.48^{\mathrm{b}}$ \\
\hline n-3 PUFA & $1.27 \pm 0.34^{\mathrm{a}}$ & $1.05 \pm 0.34^{\mathrm{a}}$ & $3.29 \pm 0.39^{b}$ & $4.91 \pm 0.34^{c}$ \\
\hline n-6 PUFA & $9.57 \pm 1.31^{\mathrm{a}}$ & $11.58 \pm 1.31^{\mathrm{ab}}$ & $12.60 \pm 1.52^{\mathrm{ab}}$ & $15.02 \pm 1.31^{\mathrm{b}}$ \\
\hline PUFA/SFA & $0.24 \pm 0.04^{\mathrm{a}}$ & $0.27 \pm 0.04^{\mathrm{a}}$ & $0.34 \pm 0.04^{\mathrm{ab}}$ & $0.45 \pm 0.04^{b}$ \\
\hline$n-6 / n-3$ & $7.40 \pm 0.41^{\mathrm{a}}$ & $10.90 \pm 0.41^{\mathrm{b}}$ & $4.13 \pm 0.48^{c}$ & $3.14 \pm 0.41^{c}$ \\
\hline
\end{tabular}

LSM = least square means; SEM = standard error of LSM.

$\mathrm{a}, \mathrm{b}, \mathrm{c}=\mathrm{LSM}$ with different letters in the same row significantly differ (Tukey post hoc test, $p<0.05$ )

CLA = conjugated linoleic acid; ETA = eicosatrienoic acid; EPA = eicosapentaenoic acid; DHA = docosahexaenoic acid; SFA = saturated fatty acids, MUFA = monounsaturated fatty acids, PUFA = polyunsaturated fatty acids

*sum of isomers of octadecenoic acid

semitendinosus had different pattern regarding the production system. There was no difference found in values of myristic acid (C14:0) while palmitic acid (C16:0) was the highest in MGSC group and the lowest in G group. The lowest percentage of stearic acid (C18:0) was measured in GS group. No effect of production system on total SFA in diaphragmae was found (Table 4). The same is true also for stearic (C18:0) and arachidic acid (C20:0), while the percentage of myristic acid (C14:0) was higher in GS group. Production system also had no effect on SFA content in study of Simčič et. al (2013) where they studied the meat FA composition of Cika bulls from intensive TMR fed or grazed bulls. The percentage of total and individual SFA were affected by production system in the study of Humanda et al. (2012) where levels of SFA were significantly lower in animals fattened on pasture. In comparison to intensive fattening the percentage by weight of palmitic acid was higher in meat of grazed bulls in all three muscles. Diets rich in concentrate have higher energy values and bovines concentrate this excess energy in adipocytes as triglycerides, which are rich in SFA, especially palmitic acid (Humanda et al., 2012). Higher values of palmitic acid in intensively compared to extensively fattened bulls or heifers was determined in many studies (De la Fuente, 2009; Humanda et al., 2012; Simčič et al. 2013).

The production system had a major impact on weight percentage (wt\%) of MUFA. Bulls from grazing production system contained significantly lower $w t \%$ of total MUFA in meat compared to bulls fed silage and concentrates. The same is also true for the sum of isomers of octadenoic acid, probably mainly oleic fatty acid (C18:1). This ratio was found in all three studied muscles. Higher values of MUFA in extensive production system is in 
agreement with many studies (De la Fuente et al., 2009; Humanda et al., 2012; Simčič et al., 2013). Regarding the human health, higher levels of oleic acid in the diet would be considered preferential as it has been found to increase HDL-cholesterol and decrease LDL-cholesterol concentrations in plasma and therefore protect against chronic heart diseases (CHD) (FAO, 2010).

The levels of PUFA were significantly affected by production system in all three muscles. Bulls from production systems that included grazing showed an increased amount of total PUFA in comparison to the bulls fed silage and concentrates. The same was also true for the n-3 PUFA, but as considered n-6 PUFA there was no difference found in longissimus thoracis (Table 2). In other two muscles the weight percentage of n-6 PUFA was higher in GS and G groups. Many studies have demonstrated that feeding cattle diets rich in forage decrease the n-6/n-3 PUFA ratio (French et al., 2000; Razminowicz et al., 2006). In this study the n-6/n-3 PUFA ratio in all three muscles was lower and thus preferential in meat of grazing bulls. According to DACH (2008) nutrition guidelines the recommended $n-6 / n-3$ ratio is $5: 1$, but in human diets this ratio is often above 10:1 and is connected with many chronic diseases. The main long chain FA in the n-3 family were EPA and DHA, which are of special interest in the human diet as they reduce the risk of cancer and cardiovascular disease. In addition, n-3 PUFA provide protection against other chronic and metabolic diseases such as obesity, diabetes, osteoporosis, neurological degeneration and bone fractures (Saini and Keum, 2018). The weight percentage of EPA and DHA was significantly higher in meat from grazing bulls. This could be the result of higher content of $\alpha$-linolenic acid in the pasture, which is the precursor in synthesis of longer chain n-3 PUFA such as EPA and DHA. These results are in agreement with the study of de la Fuente et al. (2009) and Humanda et al. (2012). Ruminant dairy and meat products are the principal sources of cis-9,trans-11 CLA isomer in the human diet. In recent years, the CLA has received much attention since it has some biological benefits such as reduction of carcinogenesis, atherosclerosis, inflammation, obesity and diabetes (Yang et al., 2015). Regarding CLA, the higher percentage was measured in meat from grazing bulls in all three muscles, but higher percentage was significant only in the GS group. De la Fuente et al. (2009) reported significantly higher concentration of CLA in longissimus thoracis of the animals fattened exclusively on pasture, while the lowest concentrations were observed in intensive production systems. Our results are also in accordance with French et al. (2000) who reported that diets high in $\alpha$-linolenic acid such as fresh grass, results in an increased deposition of CLA in muscle.
Regarding PUFA/SFA ratio, bulls from grazing feeding regime had higher and thus from human health point of view beneficially ratio in all three muscles. That was demonstrated before in a study of Razminowicz et al. (2006) and Humanda et al. (2012).

\section{CONCLUSION}

Data presented here demonstrate considerable differences in FA profiles of beef from different production systems. Meat from grazed bulls had higher content of MUFA but there were no differences found in content of SFA except in semitendinosus where only group of bulls that were fattened on pasture from spring to autumn and slaughtered at age less than two years had lower content of SFA. There were also differences found in PUFA content between different production systems. Meat from grazed bulls had higher content of some desirable PUFA ( $\alpha$-linolenic, EPA, DHA) and also lower n-6/n-3 PUFA ratio than meat from bulls fed silage and concentrate. Therefore, grazed bulls provide healthier meat for human consumption.

\section{REFERENCES}

Alfaia, C. P. M., Alves, S. P., Martins, S. I. V., Costa, A. S. H., Fontes, C. M. G. A. Lemos, ... Prates, J. A. M. (2009). Effect of the feeding system on intramuscular fatty acids and conjugated linoleic acid isomers of beef cattle, with emphasis on their nutritional value and discriminatory ability. Food Chemistry, 114: 939-946. https://doi.org/10.1016/j.foodchem.2008.10.041

Cividini, A., Levart, A., Žgur, S., Kompan, D. (2014). Fatty acid composition of lamb meat from the autochtonous Jezersko-Solčava breed reared in different production systems. Meat Science, 97, 480-485. https://doi.org/10.1016/j. meatsci.2013.12.012

DACH. (2008). Referenzwerte für die Nährstoffzufuhr. Neustadt an der Weinstrasse: Umschau.

De la Fuente, J., Díaz, M. T., Álvarez, I., Oliver M. A., Font I Furnols, M., Sañudo, C., ... Cañeque, V. (2009). Fatty acid and vitamin $\mathrm{E}$ composition of intramuscular fat cattle reared in different production systems. Meat Science, 82, 331-337. https://doi.org/10.1016/j.meatsci.2009.02.002

FAO. (2010). Fats and fatty acids in human nutrition. Report of an expert consultation (FAO Food and nutrition paper No. 91). Retrieved from http://foris.fao.org/preview/255530ece4cb94ac52f9a25af77ca5cfba7a8c.pdf

French, P., Stanton, C., Lawless, F., O’Riordan, E. G., Monahan, F. J., Caffrey, P. J., Moloney, A. P. (2000). Fatty acid composition, including conjugated linoleic acid, of intramuscular fat from steers offered grazed grass, grass silage, or concentrate-based diets. Journal of Animal Science, 78(11), 2849-2855. https://doi.org/10.2527/2000.78112849x 
Humanda, M. J., Serrano, E., Rollands, D. C., Dugan, M. E. R. (2012). Production system and slaughter age effects on intramuscular fatty acids from young Tudanca bulls. Meat Science, 90, 678-685. https://doi.org/10.1016/j.meatsci.2011.10.013

Kamihiro, S., Stergiadis, S., Leifert, C., Eyre, M.D ., Butler, G. (2015). Meat quality and health implications of organic and conventional beef production. Meat Science, 100, 306-318. https://doi.org/10.1016/j.meatsci.2014.10.015

McClance, R. (1998). Fatty acids: Seventh supplement to the Fifth Edition of McCance \& Widdowson's The composition of Foods. Cambridge: The royal society of Chemistry.

Muller, L. D., Delahoy, J. E. 2004. Conjugated linoleic acid (CLA) implications for animal production and human health (Penn State, College of Agricultural science, Cooperative extension). Retrieved from ftp://s173-183-201-52.ab.hsia. telus.net/Inetpub/wwwroot/DairyScience/Resources/NTS/ PSU_CLA.pdf

Park, P. W., Goins, R. E. (1994). In situ preparation of fatty acid methyl esters for analysis of fatty acid composition in foods. Journal of Food Science, 59(6), 1262-1266. https:// doi.org/10.1111/j.1365-2621.1994.tb14691.x

Razminowicz, R. H., Kreuzer, M., Scheeder, M. R. L. (2006). Quality of retail beef from two grass-based production systems in comparison with conventional beef. Meat Science, 73, 351-361. https://doi.org/10.1016/j.meatsci.2005.12.013

Saini R. K., Keum Y.-S. Omega-3 and omega-6 polyunsaturated fatty acids: Dietary sources, metabolism, and significance - A review. Life sciences. 203, 255-267. https://doi. org/10.1016/j.lfs.2018.04.049

SAS. (2001). User's Guide: Statistics, Version 6. Cary, NC, USA: SAS Institute Inc.
Scollan, N. D., Dannenberger, D., Nuernberg, K., Richardson, I., MacKintosh, S., Hocquette, J. F., Moloney, A. P. (2013). Enhancing the nutritional and health value of beef lipids and their relationship with meat quality. Meat Science, 97, 384-394. https://doi.org/10.1016/j.meatsci.2014.02.015

Shingfield, K. J., Bonnet, M., Scollan, N. D. (2013). Recent developments in altering the fatty acid composition of ruminant-derived foods. Animal, 7, 132-162. https://doi. org/10.1017/S1751731112001681

Shingfield, K. J., Chilliard, Y., Toivonen, V., Kairenius, P., Givens, D. I. (2008). Trans Fatty Acids and Bioactive Lipids in Ruminant Milk. In Z. Bösze (Ed.), Advances in Experimental Medicine and Biology. Bioactive components of milk, (pp. 3-65). Gödöllo, Hungary: Agricultural Biotechnology Center. https://doi.org/10.1007/978-0-387-74087-4_1

Simčič, M., Stibilj, V., Kompan, D., Čepon, M., Žgur, S. (2013). The effect of Production System on Fatty Acid Composition in Beef Meat of Cika Young Bulls. Agriculturae Conspectus Scientificus, 78, 281-284.

Wood, J. D., Enser, M. (2017). Manipulating the fatty acid composition of meat to improve nutritional value and meat quality. In: P. Purslow (Ed.), Woodhead Publishing Series in Food Science, Technology and Nutrition. New aspects of meat quality: From genes to ethics (pp. 501-535). Duxford, UK: Woodhead Publishing. https://doi.org/10.1016/B978-0-08100593-4.00023-0

Yang, B., Chen, H., Stanton, C., Ross, R. P., Zhang, H., Chen, Y. Q., Chen, W. (2015). Review of the roles of the conjugated linoleic acid in health and disease. Journal of Functional Foods, 15, 314-325. https://doi.org/10.1016/j. jff.2015.03.050 